\title{
Understanding and explaining the meaning of words by younger age school children
}

\author{
[Porozumenie a vysvetlovanie vyznamov slov u deti mladsieho skolskeho \\ veku]
}

\author{
Zdenka Kumorova
}

DOI: $10.18355 /$ XL.2020.13.02.08

\begin{abstract}
Targeted communication strategies arriving from nearby surroundings form the linguistic expression of children and upgrade their speaking to a higher developmental level. Therefore, it is desirable to observe the effect of the surrounding environment on the language development of a child. Our study interprets the description of the vocabulary of chosen terms while it observes the semantic and grammatic formation of a described word by children ( $6-10$ years old). We are going to notice the systematicity, analogy, or variability through semantic meaning or the connectivity of expression with other connotations. If a child experiences a lack of linguistic stimuli coming from the surrounding environment, the resulting slower development of his/her language skills can be a poor vocabulary, making it difficult to form more complex syntactic structures and limiting the child's communication to a narrow range of active vocabulary. The target group of children (6 to 10 years of age) was tested using the dictionary sub-test of the Weschler Intelligence Scale for Children (WISC), consisting of 30 words designed for 6 17 years old children. Despite it being a sub-test of an intelligence test, for achieving more complex results, the testing will require further evaluation on a psychological level, but in the given study, we offer interpretations from the linguistic point of view - language as a pragmatic tool of communication and thinking. Using this diagnostic tool, we have studied the understanding of vocabulary in a group of respondents - pupils of the 1st to 3rd years of study at various basic schools in Slovakia. We derived from the fact that children possess more extensive passive vocabulary than the active one, which means that they understand more words than they actively use when communicating. The reflection of individual vocabulary can be observed through the expression and interpretation of words from our research dictionary. What can be a problem for children is not the recognition and understanding of a particular word itself, but the child's expressive and explaining skills. The result of measuring the understanding of the meaning of words highly depended on the expressive skills of respondents because the performance in the dictionary test was affected by respondents' expressive skills, not only the words' knowledge.
\end{abstract}

Key words: linguistic expression, language development of a child, passive vocabulary, active vocabulary, meaning of words, expressive skills

\begin{abstract}
Abstrakt
V našej štúdii interpretujeme opis slovníka vybraných pojmov, pričom si všímame sémantické a gramatické stvárnenie opisovaného slova u detí vo veku 6 - 10 rokov. Poukážeme na systematickost', analógiu či aj inakost' prostredníctvom sémantického významu či spájatel'nost' výrazu s inými konotáciami. Ak má diet’a nedostatok rečových stimulov od najbližšieho okolia, tak výsledkom spomaleného vývoja reči môže byt' chabá slovná zásoba neumožňujúca tvorbu zložitejších syntaktických konštrukcií a obmedzenie komunikácie diet'at'a na úzky diapazón aktívnej slovnej zásoby. Respondentov vo veku 6 - 10 rokov sme testovali pomocou slovníkového subtestu Weschlerových inteligenčných škál (WISC) pozostávajúci z tridsiatich slov určeného pre deti od 6 do 17 rokov. Napriek tomu, že ide o subtest inteligenčného
\end{abstract}


testu, bude si testovanie vyžadovat' d'alšie zhodnotenie na psychologickej rovine, aby boli výsledky komplexnejšie, no v danej štúdii poskytneme interpretácie z jazykového hl'adiska ako pragmatického nástroja na komunikovanie a myslenie. Prostredníctvom tohto diagnostického nástroja sme skúmali porozumenie slovnej zásoby u respondentov $1-3$ ročníka na troch rôznych slovenských základných školách. Vychádzali sme z toho, že diet’a má rozsiahlejšiu pasívnu slovnú zásobu ako aktívnu slovnú zásobu, $\mathrm{s}$ tým súvisí fakt, že diet’a viac rozumie slovám, ako ich používa $\mathrm{v}$ komunikačnej praxi. Odraz individuálnej slovnej zásoby je možné pozorovat' aj na samotnej expresii a interpretácii slov nášho výskumného slovníka. Problematické pre diet'a môže byt' nie samotné spoznanie a porozumenie významu konkrétneho slova, ale jeho vyjadrovacie a teda vysvetl'ovacie schopnosti. Výsledok merania porozumenia významu slov bolo vysoko závislé na expresívnych schopnostiach respondentov, lebo do výkonu $\mathrm{v}$ slovníkovom teste sa premietli aj jazykové vyjadrovacie schopnosti, nielen znalost' slov.

Kl'účové slová: jazykový prejav, jazykový vývin diet'at'a, pasívna slovná zásoba, aktívna slovná zásoba, porozumenie významu, jazykové vyjadrovacie schopnost

\section{Úvod}

Lexika detskej reči je špecifická a z hl'adiska vývinu, rozmanitosti funkčného využitia, sémantizácie a tiež rozsahu. Z toho dôvodu ju nemožno porovnávat' so slovníkom dospelého človeka ani z diachronického, ani synchronického aspektu (Mistrík, 1997: 86). Ked’že lexika je vo vzt’ahu s ostatnými jazykovými jednotkami a okrem formy poskytuje jazyku aj bohaté jazykové stvárnenie významu, nemožno osvojovanie slovnej zásoby považovat' za jednoduchý proces, u diet'at’a predovšetkým. Lexika v symbióze so syntaktickými a morfologickými vzt’ahmi je t’ažko uchopitel'ná pre detské jazykové myslenie. Preto pri skúmaní jazykového vývinu u diet'at'a nemožno izolovane skúmat' len slovný fond diet'at'a, skúmat' treba aj gramatické vlastnosti osvojenej lexiky, pretože rast lexikálnych a gramatických znalostí sú úzko previazané (Smolik, Galkova, 2014: 76). Autori sa tiež odvolávajú na výsledky výskumov kognitívnych vied v oblasti modularity kognitívnych procesov poukazujúc na relatívnu samostatnost' mechanizmov špecializovaných na spracovanie určitého typu informácie (porov. Fodor, 1984, In Smolík, Gálková, 2014: 76). Poukázaním na relatívnu samostatnost' fungovania a osvojovania si lexikálneho a gramatického modulu vzíde otázka, ako optimálne metodologicky uchopit' osvojovanie jazykových znalostí detí. V súlade s rozdielnymi kognitívnymi procesmi v rámci jednotlivých jazykových rovín osvojovania jazyka je táto teória opodstatnená pri sledovaní kombinovania a skladania lexém pomocou gramatických pravidiel. Individuálny slovný fond diet'a nadobudne pamät'ovým osvojovaním, ktorému predchádza explicitné učenie slov ukazovaním na predmety, predvádzaním rôznych činností a imitovaním zvukovej podoby nejakého slova. Naopak, osvojovanie gramatického systému u diet'at'a explicitne neaplikujeme, diet'a si neosvojuje gramatické pravidlá uvedomovane, nepoukazuje sa na ich fungovanie v reči, napriek tomu si ich diet’a v priebehu vývinu reči samo osvojí. Tento jazykový mechanizmus naznačuje nativististická teória Chomského (1964) pri prezentovaní vrodených štruktúr, ktoré doplnia informácie získané $\mathrm{z}$ prostredia a $\mathrm{v}$ súlade $\mathrm{s}$ nadobudnutou jazykovou skúsenost'ou určujú podobu gramatiky. S touto teóriou pracujú viacerí psycholingvisti, teda že gramatický systém diet’a nenadobudne explicitným demonštrovaním, odvodzovaním či analyzovaním prezentovaných jazykových javov. „Pri osvojovaní gramatiky teda diet’a hrá aktívnu rolu, interpretuje počutý jazyk podl'a obmedzenia a vzorov, ktoré sú dané vrodeným vybavením“ (Smolik, Galkova, 2014: 77).

\section{Diagnostika porozumenia významov slov u detí mladšieho školského veku}

Rozvoj detskej reči možno sledovat' v jeho vývinových štádiách, pričom možno pozorovat' prudký nárast po kvantitatívnej aj kvalitatívnej stránke. Cielené komunikačné

XLinguae, Volume 13 Issue 2, April 2020, ISSN 1337-8384, ISSN 2453-711X 
stratégie zo strany blízkeho okolia formujú jazykový prejav diet’ata a posúvajú reč diet’at’a na vyššiu vývinovú úroveň, preto je vhodné sledovat' aj vplyv okolia na jazykový vývin diet’ata. Gramatická a lexikálna výbava materinského jazyka u priemerných šest'ročných detí by mala byt' uplatňovaná v rečovej praxi obdobne ako u dospelého človeka. Možno teda povedat', že synkretizmus (nerozčlenenost') lexiky gramatiky detskej reči trvá asi do polovice tretieho veku a až potom sa začne diferencovat' lexikologická rovina od gramatickej (porov. napr. potrebovam, vjú a iné). Diet’a by už v piatom roku života malo disponovat' slovnou zásobou približne 1500 až 2000 slov všetkých slovných druhov, ktoré dokáže plnohodnotne využívat' $\mathrm{v}$ dlhších spontánnych prehovoroch a dialógoch rôznorodého komunikačného obsahu so správnou gramatikou a štylistikou (Kesselova, 2018). Z hl'adiska sémantiky a gramatiky je jazykový prejav na vysokej úrovni v predškolskom veku 5.-6. roku života s rozsiahlou slovnou zásobou približne 2500 až 3000 slov. V tomto období by diet'at'u nemalo robit' problém tvorit' dlhšie súvislé prejavy $\mathrm{v}$ rôznych komunikačných situáciách, v d'alšom období vývinu diet’at’a sa dolad’uje štylistická stránka prejavu detského jedinca (Kapalkova, Slancova, 2017). V našom výskume sa zameriavame na deti nižšieho školského veku. Ak má diet’a nedostatok rečových stimulov od najbližšieho okolia, tak výsledkom spomaleného vývoja reči môže byt' chabá slovná zásoba neumožňujúca tvorbu zložitejších syntaktických konštrukcií a obmedzenie komunikácie diet'at’a na úzky diapazón aktívnej slovnej zásoby (porov. Klimovic, Kresila, Liptakova, 2017). Odborníci upozorňujú aj na opačný extrém, ktorý vzniká pri nadmernom zat’ažovaní detí osvojovaním si novej slovnej zásoby či zahrňovaní komunikačnej pozornosti zo strany rodičov (Kapalkova, Polisenska, 2013). Takéto deti sa môžu začat' prejavovat' negativisticky a môžu mat' aj neurotické prejavy (Baranovska, Doktorova, Kumorova, 2018: 54).

Ciel'ovú skupinu respondentov sme testovali pomocou slovníkového subtestu Weschlerových inteligenčných škál (WISC) pozostávajúci z tridsiatich slov, ktorý je vekovo obmedzený pre ciel'ovú skupinu respondentov pre od 6 do 17 rokov. Prostredníctvom tohto diagnostického nástroja sme skúmali porozumenie slovnej zásoby u respondentov od $6-10$ rokov, teda žiakov 1. (23 žiakov), 2. (11 žiakov), 3. (8 žiakov) ročníka (spolu 42 respondentov) na troch rôznych slovenských základných školách $\mathrm{v}$ Západoslovenskom (Trnava) a Stredoslovenskom kraji (Tvrdošín). Ked’že, že ide o subtest inteligenčného testu, bude treba zrealizovat' d'alšie testovanie a zhodnotenie prejavu detí na psychologickej rovine pre komplexnejší pohl'ad na problematiku. V našej štúdii poskytneme interpretácie len z jazykového hladiska ako pragmatického nástroja na komunikovanie a myslenie. Predpokladali sme, že diet’a má rozsiahlejšiu pasívnu slovnú zásobu ako aktívnu slovnú zásobu, znamená to, že diet’a viac rozumie slovám, ako ich používa $\mathrm{v}$ komunikačnej praxi a to možno zretel'ne zachytit' pri samotnej expresii a interpretácii slov nášho výskumného slovníka. Diet’a má vo veku $6-10$ rokov individuálnu slovnú zásobu pomerne širokú, preto pre diet’a, predpokladáme, nie je problematické samotné porozumenie slovníkovému významu konkrétneho slova, ale jeho vyjadrovacie a teda vysvetl'ovacie schopnosti. Výsledok merania porozumenia významu slov je vysoko závislé na expresívnych schopnostiach respondentov, lebo do výkonu v slovníkovom teste sa premietnu aj jazykové vyjadrovacie schopnosti, nielen znalost' slov (porov. Hanan, 2017, Solik, Malkova, 2004: 198).

Optimálne sémantické stvárnenie slova, resp. vyjadrenie vzt’ahu lexikálnej jednotky ku skutočnosti, ktorá v slove odráža to, či danej jazykovej jednotke rozumieme, aj to, ako ju vhodne použijeme vo vlastnom jazykovom prejave. Pri uvádzaní optimálneho významu ako signálu porozumenia slov u detí vychádzame z porovnania výkladov s výkladovými slovníkmi Krátky slovník slovenského jazyka (2003) a Súčasný slovník slovenského jazyka (2006). Výklady slov u detí majú rôznu povahu, identifikovali sme ich s obdobnými znakmi definícií ako v KSSJ (2003): 
1. pomocou opisu, kde sme zachytili rozhodujúce významové prvky nevyhnutné na identifikáciu daného predmetu alebo javu a zároveň na odlíšenie od iných príbuzných predmetov či javov. V opisoch sme bud' identifikovali všeobecné kategórie, alebo aj diferenčné prvky, prípade len jednu z týchto kritérií opisu výkladu. Opis významu sa konkretizuje uvádzaním synoným, antoným, príkladov, často sú uvádzané príklady izolovane od opisu a dopĺn̆ané rôznymi štylistickými kvalifikátormi, najčasnejšie u detí označujúce expresívnost', hovorovost', zriedkavo odbornost'. U detí sa vyskytoval aj opis významových odtienkov, ktorý sa objavil pri základnom opise ako pridružený spresňujúci opis, alebo sme našli len opis významového odtienka ( $v$ KSSJ sa vyskytuje po bodkočiarke po uvedení základného významu).

2. pomocou synonyma (ak slovo malo podobný alebo rovnaký význam s približne rovnako štýlovou hodnotou a bolo teda členom synonymického radu so slovom v našom dotazníkovom slovníku) alebo antonyma. Spoluautori Smolík a Malkova (2014) upozorňujú na oslabenie či nepresnost' významu pri interpretácii významu respondentom, ak nejde o pravú synonymiu, pretože žiaci podávajú širší význam, prípadne štylistický príznak slova, ktorý posúva primárny opis lexémy. V našom výskume sme sa s týmto javom viackrát stretli, ked' sme museli citlivo posudzovat' vhodnost' zvoleného synonyma respondentmi, aby sme heslo mohli určit' ako správne vysvetlené, resp. objektívne zhodnotit', či je odpoved' vyhovujúca, alebo už sa odchýlila od prvotného významu výrazne.

1. heslo HODINKY definuje výkladový slovník príkladmi (KSSJ, 2003) ako náramkové al. vreckové hodiny, pričom primárne vychádza aj so všeobecného opisu hesla hodiny poukazujúc na funkčnost', nielen na výzor tohto prístroja s príslušnými frekventovanými konotáciami: prístroj na meranie času; $h$. idú dopredu, tikajú. Žiaci prvého aj druhého ročníka vysvetlili lexému hodinky najčastejšie v konotáciách merajú čas či ukazujú, kol'ko je hodin, pretože explicitne nevedeli vysvetlit' pojem hodinky v súlade so slovníkovým výkladom. No vedeli vysvetlit' funkciu, použitie a vzhl'ad pomocou príbuznej lexémy hodiny. Vzhl'adom na tendenciu vysvetl'ovat' predmet obdobným opisom u viacerých žiakov, potvrdila sa nám teória, že deti interpretujú slová určitým spôsobom (Markman, 1994), teda, že pomenúvajú slová ako celé objekty, nie ich časti. Preto sa ani pri tomto opise, ani pri d’alších opisoch iných hesiel žiaci nesústredili na detaily predmetov a javov. Pri konotáciách sa objavilo slovo tikajú, ktoré doplnilo a umocnilo význam slova hodinky. Žiaci nevedeli nájst' správny názov na opis hodiniek príkladom ako náramkové $h$., no približoval sa $\mathrm{k}$ ich vlastným príkladom na ruku, preto sme to uznali ako signál poznania lexémy. Z hl'adiska syntaktickej platnosti žiaci preferovali vysvetl'ovanie hesiel pomocou jednoduchých eliptických podrad’ovacích súvetí s vedlajšími vetami prívlastkovými alebo predmetovými (1. ročník 34,4 \%, 2. ročník 27,3\%); zvyšok žiakov uplatnil jednoduché rozvité vety s predmetom a zamlčaným podmetom (1. ročník $21,5 \%$, 2. ročník $36,4 \%$ ). Úspešnost' vysvetlenia lexémy bola u prvákov vysoká $(78,1 \%)$ a u druhákov $(72,8 \%)$.

2. heslo DÁŽDNIK opisuje SSSJ (2006) ako roztváratel'nú ochrannú pomôcku proti dažd’u pozostávajúcu z dlhšej rúčky a konštrukcie potiahnutej nepremokavou látkou. Žiaci 1. triedy $\mathrm{z}$ hladiska zloženia vety vysvetlili slovo pomocou neúplných eliptických podrad'ovacích súvetí vedl'ajších viet prívlastkových, predmetových či príslovkového určenia času počtom $43 \%$ obdobne ako žiaci 2. triedy (91\%). Kesselova (2011:83) v rámci ontogenézy jazykového prejavu detí hovorí o zvýšenom formulačnom úsilí pri tvorbe prvých súvetí, čo sa prejavuje $\mathrm{v}$ dočasnom náraste nezrozumitel'ných častí výpovede. Ostatné vety podl'a zloženia u prvákov $(8,6 \%)$ tvorili jednoduché dvojčlenné neúplné rozvité vety $\mathrm{s}$ predmetom. Z lexikálneho hl'adiska nebol u žiakov ani tak s porozumením hesla dáždnik, ako s jeho samotným optimálnym vysvetlením. Pre neúplné a nevhodné vysvetlenie sme nemohli akceptovat' až 10 opisov žiakov 1 . triedy a 2

XLinguae, Volume 13 Issue 2, April 2020, ISSN 1337-8384, ISSN 2453-711X 
opisy žiakov 2. triedy, išlo o alúzie na činnosti zaspat', zobudit' sa, meškanie, resp. izolované lexémy dážd' a pršanie. Ako vhodné opisy sme prijali konotácie súvisiace s ochranou pred dažd'om, ktorých bolo spoločne 56,4 \% u prvákov a $91 \%$ u druhákov. Až takmer u polovice prvákov sme zaznamenali problémy s expresívnymi schopnostami, nie skôr s porozumením. U žiakov starších ako 8 rokov sa nezist'ovala znalost' významu prvých dvoch lexém.

3. heslo KRAVA vo výkladovom slovníku charakterizujeme ako vel'ké prežúvavé domáce zviera chované najmä pre mlieko a mäso; jeho samica, pričom súčasne sa za opisom uvádzajú frekventované konotácie spojené s týmto slovom: pást' kravy, dojná krava. Pri prihniezdenom slove kravský sú rovnako uvedené konkretizujúce príklady: $k$. roh, $k$. mlieko. Žiaci prvého ročníka definovali pojem krava najčastejšie prostredníctvom špecifikačnej kategórie mlieko/mliečko $(100 \%)$ v spojení so slovesom v 3. os. sg. dáva, vyrába, slúži na, tvorí. Obdobne to bolo v2. ročníku, kde žiaci vysvetlili pojem najčastejšie slovom mlieko (91\%), len 4-krát sa vyskytovalo slovo zviera/zvieratko, no u jedného žiaka sa spomenuli všetky kategórie opisu slova v základnom výklade - zviera, mlieko, mäso. Ide o konkretizáciu opisu prostredníctvom ustálených konotácí́ k danému heslu. Je to rozdiel oproti žiakom 3. ročníka, pretože žiaci 1. ročníka uplatnili zovšeobecňujúcu kategóriu opisu zviera/zvieratko len 2-krát z 23. Zaujímavé je u prvákov sledovat', oproti žiakom z vyšších ročníkov, využívanie emocionálno-expresívnych príznakov v podobe zdrobnenín mliečko $(55,9 \%)$, zvieratko $(4,3 \%)$. Žiaci 3. ročníka ako $9-10$ ročné deti mali vysvetlit' slová až od tretieho hesla krava. Vysvetlenie slova krava v 3. ročníku žiaci volili najčastejšie lexémou zviera ako zovšeobecňujúcou kategóriou (75\%). Prívlastok domáce možno považovat' už za špecifikačný prvok, ktorý označil len 1 žiak. Slovo je z jadra slovnej zásoby, žiak sa s ním frekventovane stretáva už od útleho veku, a preto pri ňom boli uvedené aj konotácie spájajúce sa funkčne s heslom krava: dobytok, gazdovský dvor, hospodárske zviera. Tieto spojenia sa do významovej charakteristiky nezapočítavajú, ale korešpondujú s porozumením diet'at'a a potvrdzujú aj rozšírenú slovnú zásobu u detí tohto veku. Prváci $(73,1 \%)$ a druháci $(81,9$ \%) spájali lexémy z hl'adiska skladby prevažne pomocou jednoduchých dvojčlenných rozvitých viet s predmetom so zamlčaným podmetom, tretiaci na opis pojmu uplatnili zväčša eliptické podrad'ovacie súvetie s vedl'ajšou vetou prívlastkovou (75\%).

4. heslo ZLODEJ možno vykladat' opisom s príkladmi ako ten, kto kradne, okráda: vreckový zlodej, zlodej sa vlámal do bytu. V hesle zlodej žiaci všetkých ročníkov odpovedali zovšeobecňujúcou kategóriou kto kradne (1. ročník 17 z 23, 2. ročník 10 z 11, 3. ročník 6 z 8), resp. prihniezdeným slovesom vykráda (1. ročník 3 z 23, 2. ročník 1 z 11, 3. ročník 1 z 8), okráda (3. ročník 1 z 8). Niektorí žiaci uvádzali aj spresňujúce konotácie, ako napr. človek, ktorý kradne (1. ročník 1 z 23, 2. ročník 1 z 11, 3. ročník 7 z 8). Poukázanie na osobu človek korešponduje so slovníkovým výkladom so zámenom kto. Zosobnenie konania na človeka sme $\mathrm{v}$ prípade žiakov 1. ročníka postrehli len $\mathrm{v}$ jednom prípade $(4,3 \%)$ prostredníctvom spojenia ujo, ktorý kradne, ale u tretiakov to bolo až $87,5 \%$, ostatné prípady sa nezosobňovali na konkrétnu osobu, žiaci uvádzali v ostatných prípadoch sloveso najčastejšie v 3 . os. sg. alebo pl. Pri hesle sa uvádzali u všetkých žiakov frekventovane aj predmetové vzt'ahy: vykráda domy, budovy a banku, kradne veci, peniaze, šperky, hodinky kradne (1. ročník 22-krát, 3. ročník 6-krát). V porovnaní mladších žiakov so staršími sme si všimli rozdiel v uprednostňovaní syntaktickej konštrukcie na vyjadrenie sa. Kým pri prvákoch $(77,4 \%)$ a druhákoch $(81,9 \%)$ sa všeobecne uplatnila jednoduchá rozvitá veta, prevažne neúplná so zamlčaným podmetom ((on)kradne čo?), tak u tretiakov $(87,5 \%$ ) prevažovalo podrad'ovacie súvetie s vedl'ajšou vetou prívlastkovou (človek, ktorý kradne). V jednom prípade sa vyskytol aj explicitne vyjadrený negatívny hodnotiaci parameter v podobe lexémy zlý. Táto lexéma je z jadra slovnej zásoby a žiaci ju funkčne využívajú v komunikácii. Pri opise hesiel slovesami sme pozorovali rôzne označovanie kategórie osoby, resp. označenie neosobnými tvarmi (doji 
sa, nosí sa, sa preváža, môže sa vozit;; je chované), no v prípade hesla zlodej sme pozorovali na kategórii osoby jednoznačnú osobnú dištancovanost' detí k negatívnemu významu lexémy zvolením 3. os. sg.: kradne/vykráda/okráda.

5. heslo KLOBÚK v slovníku (KSSJ, 2003) zodpovedá dvom výkladom základného a sekundárneho významu, v prípade odpovedí detí v ZŠ odznel len základný význam s jeho príslušnými konotáciami: prikrývka hlavy z pevnejšieho materiálu (so strieškou): založit' si k., dat'si k. na hlavu. V prípade hesla klobúk všetci žiaci 3. ročníka (100\%) odpovedali špecifikačnou kategóriou s predložkou na hlavu, no v prípade prvákov len $25,8 \%$ a druhákov 27,3\%. Všeobecná pomenovacia kategória prikrývka sa objavila v slovotvorne motivujúcom slovesnom podstatnom mene prikrytie u všetkých žiakov len raz (3. ročník 1 žiak). Na identifikáciu predmetu žiaci využili namiesto opisu prikrývka na hlavu spojenie vec (4-krát v 3. roč.) či oblečenie ( 2 v 3. roč.), čiapka (2-krát v 2. roč.), čo sa príliš vzdialilo od pôvodnej pomenovacej funkcie významu slova, pretože ide o všeobecné označenia pomenovania. Žiaci zvolili aj iné doplňujúce označenia predmetu pomocou spojení ochránenie tela pred slnkom, aby sme sa nespálili, proti slnku, aby sme nedostali úpal, čo poukazovalo na jednostranné funkčné využitie klobúka, deti pravdepodobne nepoznali iný ciel' nosenia klobúka, ako ochrana pred nepriaznivým horúcim počasím. Zaujímavé bolo opät' porovnanie expresívnych schopností prvákov, druhákov a tretiakov: kým mladší prváci (10) a niektorí druháci (4) vysvetlovali predmet pomocou jednoduchých dvojčlenných rozvitých viet s predmetom a so zamlčaným podmetom ((my) sa schovávame či chránime pred slnkom, nedostali úpal, nám nesvietilo slnko, nosí sa na hlave a pod.), tak tretiaci znova zvolili na vyjadrenie pojmu podrad'ovaciu syntagmu prívlastkovú (vec, oblečenie, ktoré...) $(87,5 \%)$. Niektorí prváci (8) a druháci (3) sa začali vyjadrovat' už aj pomocou jednoduchších eliptických podrad'ovacích súvetí ( 3 z 11). Už len v jednom prípade sme zaznamenali využívanie kladného emocionálno-expresívneho príznaku v podobe zdrobneniny slniečko.

6. heslo cudzieho pôvodu BICYKEL sa charakterizuje vo výkladovom slovníku opisom ako dvojkolesové jednostopové vozidlo poháňané nohami na prepravu osôb a športové účely s jeho príslušnými lexikalizovanými spojeniami a frekventovanými konotáciami: dámsky, detský b.; pretekársky b.; horský b.; jazda na bicykli. Heslo bicykel opísali žiaci 3. ročníka $(62,5 \%)$ frekventovane lexikalizovaným spojením dopravný prostriedok, resp. univerbizovanú podobu prostriedok, napriek neuvádzaniu tohto spojenia vo výkladových slovníkoch (KSSJ, 2003, SSSJ, 2006) sa táto definícia môže brat' ako relevantná, pretože sa žiaci učia v škole vymenovat' dopravné prostriedky spolu s bicyklom. Opisy sú spájané u všetkých žiakov 1., 2. a 3. ročníka so slovesami poukazujúcimi na činnost' vozit'/prevážat', prepravit', športovat', jazdit', dostat' sa, čo tento dopravný prostriedok definuje. Preto môžeme opisy považovat' ako signál porozumenia u detí a môžeme ich ohodnotit' ako definované správne vo všetkých prípadoch, pretože slovo bicykel sa už od útleho detstva vyskytuje v ich aktívnej slovnej zásobe. No v prvom a druhom ročníku sa frekventovane opisoval bicykel prihniezdeným slovotvorným variantom bicyklovat'sa, tento opis sme nemohli brat' ako relevantný, pretože bližšie neopísal funkciu predmetu. Žiaci síce pravdepodobne porozumeli heslu, ale zlyhala ich vyjadrovacia schopnost' optimálne vysvetlit' pojem, to sa odrazilo na ich celkovom hodnotení porozumenia pojmu na $38,7 \%$ prváci, druháci $54,5 \%$.

7. heslo SOMÁR je jednovýznamové podstatné meno opisované ako zviera $s$ dlhými ušami, slabo vyvinutou hrivou podobné koňovi a použivaný na nosenie nákladov, na jazdu al. do záprahu s príslušnými príkladmi híkat' ako somár, nosit' sa na somárovi. Heslo somár opisovali 5 prváci, 5 druháci a všetci tretiaci (8) všeobecnou kategóriou pomenovaním zviera, čo hodnotíme ako signál porozumenia daného hesla. U niektorých detí sa vyskytli aj bližšie špecifikačné kategórie tohto pomenovania, čím sa pomenovacia

XLinguae, Volume 13 Issue 2, April 2020, ISSN 1337-8384, ISSN 2453-711X 
schopnost' tohto hesla radikálne zvýšila: domáce, sivé, s velkými ušami, prípadne na prepravenie veci (prváci 14-krát, druháci 1-krát, tretiaci 5-krát) - to je znakom dobre rozvinutej slovnej zásoby u diet'at'a. Úspešnost' porozumenia tejto lexéme je v 1 . triede $63,8 \%, v 2$. triede $45,5 \%$, v 3. triede 100-percentná.

8. heslo STARODÁVNY sa vo výkladovom slovníku (KSSJ, 2003) definuje pomocou synonyma starobylý s príslušnými príkladmi starodávne zvyky, starodávny dom. Heslo starodávny žiaci vysvetlovali najčastejšie príkladom: s. kniha, s. kolovrátok, s. vzácna vec, staré auto, staré hodiny, zámok či pyramída, s. nábytok (prváci 4-krát, druháci 3-krát, tretiaci 4-krát) alebo synonymami: starý, vel’mi starý (prváci 8-krát, druháci 2-krát, tretiaci 4-krát), ktoré sme ako signál porozumenia heslu schválili či už ako všeobecný znak, alebo špecifikačný znak významu. Neporozumenie slovu sme zaznamenali vo väčšom počte u prvákov 47, $3 \%$, druháci 54,5\% (oproti tomu tretiaci len 12,5\%). V tomto prípade by sme za nízkym skóre videli skôr rezervy vexpresívnych schopnostiach respondentov ako v porozumení slovu.

9. heslo OPUSTIŤ je viacvýznamové slovo až s piatimi významami, pričom vodpovediach sa vyskytoval len jeho základný význam zanechat' (natrvalo) nejaké miesto, odíst' odniekial', ako napríklad opustit' mesto, miestnost', prípadne jeho prenesený eufemizmus opustit' svet vo význame zomriet' a prenesený význam zanechat' bez opory, odist' od niekoho: o. ženu, rodinu. Heslo opustit’ žiaci vysvetlili najčastejšie synonymom odíst' (prváci 7, tretiaci 3), odst'ahovat' (prváci 2, tretiaci 1), nechat' (prváci 1), ist' preč (prváci 1), no žiaci slovo opísali aj príslovkovým a predmetovým spojením je sám/nechá samého; kamarát o. kamaráta; nájdeš si iného; otec o. maminu; o. manželku (prváci 2 , druháci 3, tretiaci 4). Všetky opisy zodpovedajú významom v základnom (prváci 5, druháci 3, tretiaci 1) a prenesenom význame (prváci 9, druháci 6, tretiaci 5), v dvoch prípadoch u tretiakov a jeden u prvákov nie je zretel'ný, o ktorý význam ide, lebo stojí samostatne bez predmetu, a preto možno zhodnotit' slovo opustit' z hl'adiska porozumenia ako lexému, ktorej žiaci rozumejú. Nesprávne zodpovedané výrazy boli skôr vecou nevhodného vysvetlenia ako nepoznania významu (prváci 34,4 \%, druháci 27,2 \%).

10. heslo STATOČNÝ je prídavné meno definované opisom s príslušnými príkladmi: $k t$. koná v súlade so ct’ou, mravnost'ou, (po)čestný, poriadny, svedomitý; svedčiaci o tejto vlastnosti: s. človek, občan; s. záchranca hrdinský, odvážny. Heslo statočný žiaci charakterizovali iba pomocou synoným tak, ako to je po konkretizované po opise lexémy vo výkladovom slovníku. Žiaci však uvádzali aj iné synonymné slová ako odvážny (druháci 1, tretiaci 1), smelý (tretiaci 1), dobrý (prváci 2), pričom za správnu charakteristiku sme mohli považovat' aj opisnú podobu neboji sa (prváci 7, druháci 3 , tretiaci 5) ako synonymum k slovu hrdinský (prváci 4, druháci 2), nebojácny či smelý. V tom prípade možno uviest', že tretiaci rozumejú slovu správne a vedia ho využívat' funkčne v komunikácii, prváci nevedeli vysvetlit' význam slova až v 43 percentách a druháci až s 45,5-percentným podielom. Tieto nedostatky súviseli $\mathrm{s}$ nedostatočným a nepresným vysvetlením slova respondentom, nie pravdepodobne neporozumením významu.

11. heslo PRIEHLADNÝ je polysémantické prídavné meno, pričom žiaci uvádzali význam tohto slova $\mathrm{v}$ jeho základnom, teda neprenesenom význame súvisiacim s predmetmi, nie s morálkou: priezračný, priesvitný: priezračné sklo, šaty. Lexéma sa vysvetl'ovala pomocou zretel'ných synoným. Heslo priehl'adný žiaci frekventovane vysvetl'ovali pomocou opisu je cez neho vidiet' (prváci 4, druháci 1, tretiaci 3), ktorý sa dá stotožnit' so synonymom priesvitný (prváci 1, druháci 1) či priezračný, a preto sme túto odpoved' hodnotili ako správnu, diet'a porozumelo slovu. Za správnu odpoved' sme označili aj synonymum čistý (tretiaci 1). 3 žiaci z 3. triedy, 9 žiaci z 2. triedy a 11 žiaci z 1. triedy nepoznali význam slova, nerozumeli slovu priehl'adný, preto celková 
percentuálna úspešnost' je u prvákov 51,6 \%, druhákov 12,8 \% a tretiakov 62,5 \%. Pri 10 slove sme po prvýkrát zaznamenali u detí 9 - 10-ročných väčšie problémy $\mathrm{s}$ porozumením, u prvákov je problém s vysvetlením alebo porozumením významu už od šiesteho hesla, podobne ako u druhákov.

12. heslo NEZMYSELNÝ je viacvýznamové adjektívum s 2 významami uvádzané s frekventovanými príkladmi: 1. kt. nedáva zmysel, pochabý, hlúpy: n-é reči, nápady; 2. kt. sa prieči rozumu, nerozumný: n-á vojna, odpor je $n$. Heslo nezmyselný žiaci uviedli v jeho základnom význame bud' opisom korešpondujúcim so slovníkom, alebo synonymným výrazom typu nie je pravda, nemôže byt' (3 druháci, 4 tretiaci) a mladší žiaci uviedli konkrétny nezmyselný príklad - žaba/krava ide na bicykli, $4+4=7$ (1 prvák, 3 druháci) prípadne boli uvedené aj subštandardné synonymá blbá/blbost'/blbovina (prváci 9, tretiaci 1). 11 prváci $(47,3 \%), 5$ druháci $(45,5 \%)$ a 3 tretiaci $(37,5 \%)$ nevedeli reagovat' na heslo vôbec alebo ho zle vysvetlili, čiže títo žiaci neporozumeli slovu, nepoznajú jeho význam.

13. heslo OSTROV opisuje výkladový slovník priamym významom a metaforicky preneseným významom s frekventovanými konotáciami: 1. čast’ pevniny obkolesená vodou: o-y pri pobreží, pustý o.; 2. čo pripomína ostrov: o. snehu, o. zelene. Heslo ostrov spôsobilo pri uvádzaní významu žiakom problémy, 9 žiakov 2. triedy, 5 žiakov 3. triedy bud' úplne nepoznalo slovo, alebo vysvetlilo slovo vzdialenými analógiami na význam slova ostrov (more, ostrov, stromy atd'.). Obdobne reagovali žiaci prvého ročníka, no tí vo svojich expresívnych schopnostiach úplne zlyhali, napriek poznaniu významu tohto slova, ako naznačili slová, ktorými označovali slovo, boli však príliš všeobecné a neúplné. Preto sme toto slovo hodnotili ako nesprávne vysvetlené, napriek tomu, že isté konotácie naznačovali, že v ich slovnom fonde niekde figuruje, ale tým, že ho aktívne nevyužívajú, majú problém vysvetlit' význam slova. Celkové hodnotenie nesprávnych odpovedí u prvákov bolo $94,6 \%$, u druhákov $81,8 \%$ a u tretiakov $62,5 \%$.

14. heslo ABECEDA je viacvýznamové slovo s tromi významami, pričom odvodené významy vznikli zužovaním, špecifikovaním podl'a určitého odboru. Predpokladali sme, že tieto významy vzhl’adom na úzku konkretizáciu významu žiaci nebudú poznat', preto uvádzame len priamy, základný význam, prípadne konotácie súvisiace s týmto významom, ktorý sme hl'adali aj v odpovediach žiakov: súbor všetkých pismen istej graf. sústavy $v$ ustálenom poradi použivaný jazykovým spoločenstvom: písmená slovenskej abecedy; učit' sa abecedu; usporiadat', zoradit' slová podl'a abecedy. Heslo abeceda vysvetl'ovali žiaci opisom alebo príkladom. Opis výkladového slovníka uvádza abecedu ako súbor všetkých písomných znakov, resp. písmen, preto sme odpoved' súvisiacou $\mathrm{s}$ týmto výkladom uznali ako signál porozumenia a výskytu $\mathrm{v}$ aktívnej slovnej zásobe $\mathrm{u}$ žiaka (prváci 10, druháci 7, tretiaci 6). Uznali sme aj odpoved’, kde sa uvádzali konkrétne písmená a poukázalo sa na poradie, ktoré je rovnako dôležitým špecifikačným kritériom výkladu významu slova abeceda. So slovom abeceda sa žiaci priebežne stretávajú už od predškolského veku, a preto je súčast'ou ich aktívnej slovnej zásoby a vedia ho primerane vysvetlit', priradit' mu správne konotácie a funkčne ho definovat'. Heslu abeceda porozumeli žiaci vo vel'kom počte (prváci 68,8 \%, druháci 72,8 \%, tretiaci 87,5\%).

15. heslo BÁJKA je dvojvýznamové slovo, pričom prenesený význam je rozšírený, zovšeobecnený význam základného významu s expresívnym príznakom. Oba významy by sa mohli $\mathrm{v}$ odpovediach žiakov vyskytnút', preto uvádzame obidva $\mathrm{s}$ niektorými príkladmi: 1. poučne ladená rozprávka, v kt. zvieratá konajú ako l’udia: Ezopove b-y; 2. expr. nepravdivé rozprávanie, výmysel, rozprávka: nerozprávaj mi bájky! Heslu bájka rozumela polovica žiakov 3. ročníka, zaujímavé je, že toto heslo vôbec poznali niektorí žiaci, pretože tento literárny útvar je súčast'ou osnov na 1. stupni ZŠ až v 4. ročníku.

XLinguae, Volume 13 Issue 2, April 2020, ISSN 1337-8384, ISSN 2453-711X 
Najčastejšie ho žiaci definovali obdobne, ako je uvádzané v definíciách učebníc vo vyšších ročníkoch prvého stupňa ZŠ. Preto výklady typu rozprávka, v ktorej vystupujú zvieratá; poučná rozprávka; básnička alebo veršované diela; vymyslená rozprávka možno uznat' ako správne výklady poukazujúce na poznanie tohto slova. U 4 detí 3 triedy (50percentná úspešnost') možno tvrdit', že slovu rozumejú a vyskytuje sa v ich aktívnom fonde slovnej zásoby. Opačný prípad boli prváci, ktorí nevedeli definovat' bájku ako literárny žáner, uznali sme im však odpoved' v prenesenom význame rozprávka ako niečo vymyslené $(3=12,9$-percentná úspešnost'). Druháci boli neúspešní všetci (100 \%).

16. heslo PRINÚTIŤ je jednovýznamové sloveso, ktoré možno vyložit' opisom ako násilím, mocou, nátlakom spôsobit', aby niekto niečo urobil, donútit', resp. konkretizovat' jeho blízkymi konotáciami prinútit', aby odišiel; to urobil. Pri hesle prinútit' sa vyskytovali viaceré konotácie poukazujúce na slovníkový výklad slova, ktoré sme uznali ako správne na identifikáciu slova $\mathrm{v}$ jeho slovotvorne odvodenom dokonavom tvare: prinútit'/donútit', aby niečo spravil/robil/urobil/povedal (1. ročník 9-krát, 2. ročník 9-krát, 3. ročník 6-krát). Nátlak, násilie, rozkaz je základnou špecifikačnou kategóriou tohto slova, ktoré sa explicitne vyskytujú v uvádzaných slovesných spojeniach u prvákov 9krát, u tretiakov 1-krát. Úspešnost' porozumenia tomuto slovu bola celkovo vysoká (1. trieda $77,4 \%$, 2. trieda $89,9 \%$, 3. trieda $87,5 \%$ ), z toho možno súdit', že slovo patrí do aktívnej slovnej zásoby detí, pretože sa s ním v rodinnom či inom sociálnom prostredí majú možnost' vzhl'adom na dorozumievaciu funkciu slova stretnút' pomerne často.

17. heslo VSTREBAŤ výkladový slovník definuje základným významom s pridruženými frekventovanými konotáciami: prijat' do seba, pohltit', absorbovat: korene vstrebali všetku vlahu. Za heslom je uvádzaný aj jeho zvratný tvar VSTREBAŤ SA, ktorý uvádzame s výkladom a príkladmi rovnako, pretože sa vysvetlenia uvádzali aj u našich respondentov. Vzhl'adom na významovú totožnost' aj synonymiu možno takýto výklad považovat' za správny. Heslo vstrebat' sme uznali ako správne vysvetlené v 5 prípadoch $\mathrm{u}$ tretiakov $(62,5 \%)$, pričom najčastejšie bolo vysvetlené synonymne od zvratného slovesa vstrebat' $\mathrm{sa}=$ vsiaknut', prípadne $\mathrm{v}$ jeho konotácii: vsiaknut' krém. Za nesprávne sme považovali vysvetlenie slova prostredníctvom preneseného významu na myšlienkové obsahy typu ked' sa niečo naučím. Ostatní žiaci 3. ročníka a všetci žiaci prvého a druhého ročníka nepoznali význam slova, pretože sa vôbec nenachádzal ani v ich pasívnom fonde slovnej zásoby.

18. heslo PÝCHA sa v slovníku charakterizuje primárne $\mathrm{v}$ spojení s vlastnost'ou, $\mathrm{v}$ prenesených významoch $\mathrm{v}$ spojení s osobou alebo sebavedomím prisudzovanej osobe. Všetky tri významy sa vyskytovali u respondentov, preto ich uvádzame všetky tri s ich jednotlivými konotáciami: 1. preceňovanie seba, nadmerné sebavedomie, povýšenost, márnomysel'nost', namyslenost', nadutost': nadúvat'sa od pýchy, 2. hrdost', sebavedomie: rodičovská p., hovorit's pýchou o svojej vlasti; 3. osoba, vec, na kt. možno byt' hrdý, pyšný: syn bol pýchou rodiny. Heslo pýcha vedela opísat' väčšina žiakov 3. triedy (75\%), menej však žiaci 1 . triedy $(25,8 \%)$. Slovo sa vyskytuje u viacerých v ich aktívnej slovnej zásobe a priebežne sa s ním stretávajú starší žiaci v rámci opisu osôb a ich charakterových čŕt. Slovo opísali prostredníctvom opisných tvarov mysliet'o sebe viac = preceňovanie sa; že som dobrý, že on mysli na seba = povýšenost'. Ostatné opisy zodpovedali slovníkovému výkladu identicky: namyslený (1. trieda 2, 3. trieda 2), povyšovat' sa (1. trieda 1, 3. trieda 1) zodpovedajúce základnému významu. Význam zodpovedajúci tretiemu významu $h r d y ́$, pyšný sa objavil u prvákov 3-krát a u tretiakov 1-krát. Celkovo žiaci 3. ročníka porozumeli tomuto slovu so 75-percentným podielom, pretože vysvetl'ovali lexému primerane jej slovníkovým špecifikačným kategóriám významu. Žiaci 1. ročníka porozumeli slovu pýcha minimálne $(25,8 \%)$, žiaci druhého ročníka vôbec $(0 \%)$. 
19. heslo HAZARD sa vo výkladovom slovníku uvádza ako jednovýznamové slovo $\mathrm{z}$ okraja slovnej zásoby definované ako riskantný al. neuvážený čin, postoj, hazardérstvo, pričom sa uvádzajú aj jeho frekventované konotačné spojenia: hazard so životom; hazardná hra, hráč hrajúci o vel'ké peniaze. Heslo hazard žiaci vysvetlili často pomocou konotácie hra/hry s peniazmi; hry, pri kt. sa mínajú peniaze; hra, kt. získava peniaze (1. ročník 1,3 . ročník 4). Tento opis zodpovedá príkladom v slovníkovom výklade, preto sme odpovede označili za správne. Optimálne vysvetlenie bolo uvádzané aj pomocou lexém risk, riziko. Len polovica tretiakov (50\%) vedela však slovo hazard vysvetlit' relatívne správne, preto možno označit' slovo hazard ako patriace do pasívnej slovnej zásoby, prípadne slovo vôbec nepatrí do individuálnej slovnej zásoby našich respondentov (tak ako u prvákov 94,6 \%), pretože s nim v rámci svojej komunikačnej situácie neprichádzajú do kontaktu. Druháci boli neúspešní všetci (100\%).

20. heslo IMITOVAŤ je jednovýznamové, pričom jeho výklad významu je sprostredkovaný jeho synonymami s vhodnými spojeniami: napodobňovat', napodobnit': $i$. (hlas) speváka.. Ide o slovo latinského pôvodu, ktoré nestojí v jadre slovnej zásoby, je okrajovo využívané popri jeho synonymnej dominante napodobňovat'. Heslo imitovat' neoznačil nikto správne $\mathrm{v}$ tret’om ročníku (7 vôbec nereagovali na heslo a 1 označil význam slova nesprávne), ale v 1. ročníku označili správnu odpoved' 3 žiaci. Slovo imitovat' sa pravdepodobne častejšie nevyskytuje ani v aktívnej, ani v pasívnej slovnej zásobe. Deti v predškolskom aj školskom veku mu častejšie nerozumejú, pretože sa nevyskytuje v ich komunikačnom poli. Druháci boli opät' neúspešní všetci (100 \%).

21. heslo IZOLOVAŤ má 2 významy, pričom prvý opisuje zamedzenie osôb: oddel'ovat', oddelit' (na zamedzenie styku), separovat', napr. chorého (od zdravých) a druhý význam poukazuje na materiálne izolovanie: (o)chránit' pred tepelnými zmenami, vlhkostou, zvukom, napr. i. stavbu. Slovo izolovat' u žiakov prvého ročníka naznačilo, že mu vôbec neporozumeli, u žiakov 3. ročníka sme spozorovali prostredníctvom príkladov, že mu rozumejú 2 žiaci. Celková neúspešnost' v porozumení lexémy v 3. ročníku $25 \%$. Prváci a druháci neboli už vôbec hodnotení, pretože už od 17 slova vstrebat' začali mat' problémy s porozumením a s vysvetlovaním slov, testovanie s nimi sme skončili tromi po sebe idúcimi zápornými odpoved’ami.

22. heslo NAMÁHAVÝ je prídavné meno s významom vyžadujúci námahu, únavný, vyčerpávajúci, t’ažký: $n$-á robota, cesta, $n$. šport. Žiaci tretieho ročníka vysvetlili lexému namáhavý viacerými spôsobmi: pomocou príkladu, ako napr. $s$ domácou úlohou; pomocou priameho synonyma t’ažký (2), pomocou opisných synoným: človek, kt. robi vel'a vecí, moc pracuje, dá do toho vel’a sily (3) = vyžadujúci námahu, resp. únavný. Tretiaci dokázali slovo vysvetlit' so 75-percentnou úspešnost'ou.

23. Heslo DODATOK je vyložené ako niečo dodatočne pripojené, doplnok s pridanými frekventovanými spojeniami: $d$. $k$ dohode; napisat' $d$. ku knihe. Heslo dodatok analyzovali len niektorí tretiaci (6), pretože mnohí už skončili testovanie skôr tromi po sebe idúcimi zápornými odpoved’ami. Úspešnost' správneho vyjadrenia $\mathrm{k}$ obsahu slova bola malá (25\%), správne rozlíšili význam slova iba dvaja žiaci pomocou príkladu.

24. heslo RIVALITA je slovo z okraja slovnej zásoby pôvodom z latinčiny a jeho význam je súperenie, pretekanie sa. Čiže boj medzi protivníkmi je len skrytý, naopak, žiaci opisovali rivalitu ako priamy fyzický boj, súboj, preto boli skórovaní nulou. Úspešnost' pri opise d'alších troch slov PRECÍZNY, MIGROVAŤ, SÚŽENIE tretiakmi bola nulová, rovnako ako skórovanie pri d’alších slovách v slovníkovom subteste: JEDNOMYSEL'NÝ, BEZPROSTREDNÝ, ANOMÁLIA, BEZPROSTREDNÝ, ANOMÁLIA.

XLinguae, Volume 13 Issue 2, April 2020, ISSN 1337-8384, ISSN 2453-711X 


\section{Záver}

Pri stanovení hypotézy sme predpokladali, že porozumenie slov v slovníkovom subteste bude výrazne závisiet' na explicitných schopnostiach našich respondentov, čo sme pri interpretácii slovných jednotiek dokázali v plnom rozsahu. Naznačovali to eliptické a neúplné výpovede respondentov priebežne pri jednotlivých slovách slovníkového subtestu. Miera neschopnosti vysvetlit' pojem, ako aj miera porozumenia lexéme stúpala s poradím lexémy, ked' sa objavovali slová jednovýznamové, ktoré sa bud' vyskytovali v pasívnej slovnej zásobe respondentov, alebo sa vôbec nevyskytovali $\mathrm{v}$ ich individuálnej slovnej zásobe. Pri polysémantických slovách žiaci dokázali nájst' niektorý z významov lexémy a vysvetlit' ho, no pri jednovýznamových slovách bola ich vysvetl'ovacia schopnost' vysoko obmedzená. Slová, ktorým výrazne porozumeli, boli prevažne slová z jadra slovnej zásoby ako krava, somár, prípadne išlo o konkrétne pojmy (bicykel, dáždnik, krava, somár, klobúk), ktoré prevažovali v úspešnosti porozumenia a interpretovania nad abstraktnými pojmami. Tu možno hodnotit' lepšie vyjadrovacie schopnosti detí aj prostredníctvom duplicitných uvádzaní výkladov či už špecifikačnými, alebo konkretizačnými kategóriami opisu. Väčšina respondentov porozumela týmto heslám a vedela ich funkčne uplatňovat' v komunikačnej praxi.

Štúdia vznikla v rámci riešenia projektu VEGA 1/0454/18 Logofóbia ako prekážka rozvíjania jazykovej kompetencie pri osvojovaní si materinského a cudzieho jazyka.

\section{Bibliographic references}

BARANOVSKA, A. - DOKTOROVA, D. - KUMOROVA, Z. 2018. Dolezitost vztahovej vazby pri osvojovani si jazyka u deti. In: O dietati, jazyku, literature, vol. VI, n. 1, pp. 52- 59. ISSN 1339-3200.

HORNAKOVA, K. - KAPALKOVA, S. - MIKULAJOVA, M. 2005. Kniha o detskej reci. Bratislava: Slniecko. ISBN 80-969074-3-3.

HAMAN, E. et al. 2017. Noun and verb knowledge in monolingual preschool children across 17 languages: Data from Cross-linguistic Lexical Tasks (LITMUS-CLT) In: Clinical linguistics \& phonetics, vol. 31, n. 11-12, pp. 818-843. ISSN 14645076.

CHOMSKY, N. 1964. The Development of Grammar in Child Language: formal discussion. In: Monographs of the Society for Research in Child Development, vol. 29, pp. 35-39. ISSN 0037976X.

KAPALKOVA, S. - SLANCOVA, D. 2017. The vocabulary profile of Slovak children with primary language impairment compared to typically developing Slovak children measured by LITMUS-CLT. In: Clinical linguistics and phonetics, vol. 31, n. 11-12, pp. 893-909. ISSN 14645076.

KAPALKOVA, S. - POLISENSKA, K. 2013. Non-word repetition performance in Slovak-speaking children with and without SLI: Novel scoring methods. In: International Journal of Language and Communication Disorders, vol. 48, n. 1, pp. 78-89. ISSN 13682822.

KESSELOVA, J. 2018. Speaker's reference in dialogic communication in Slovak language: Verbal person versus personal pronoun. [Referencia na hovoriaceho $\mathrm{v}$ dialogickej komunikacii v slovencine: verbalna osoba verzus osobne zameno]. In: Slavica Slovaca, vol. 53, n. 3-4, pp. 94-108. ISSN 00376787.

KLIMOVIC, M. - KRESILA, J. - LIPTAKOVA, L. 2017. Factual text comprehension tasks as a tool for stimulating executive functions in 9- to 10-year-old children. Educational Studies in Language and Literature, vol. 17, n. Specialissue, pp. 1-22. ISSN 15676617.

Kratky slovnik slovenskeho jazyka. 2003.

KACALA, J. - PISARCIKOVA - POVAZAJ, M. 4. dopl. a upr. vyd. (Eds.). Bratislava: Veda. ISBN 80-224-0750-X.

MARKMAN, E. M. 1994. Constraints on word meaning in early language acquisition. In: Lingua, vol. 92, n. C, pp. 199-227. ISSN 00243841. 
MISTRIK, J. 1997. Stylistika. Bratislava: SPN. ISBN 80-08-02529-8.

POLISENSKA, K. - KAPALKOVA, S.- NOVOTKOVA, M. 2018. Receptive language skills in slovak-speaking children with intellectual disability: Understanding words, sentences, and stories. Journal of Speech, Language, and Hearing Research, vol. 61, n. 7, pp. 1731-1742. ISSN 10924388.

SLANCOVA, D. 2013. Werbs acquisition in early childhood. [Osvojovanie slovesnej lexiky v ranej ontogeneze reci]. Jazykovedny Casopis, vol. 64, n. 2, pp. 109-132. ISSN 00215597.

SMOLIK, F. - SEIDLOVA MALKOVA, G. 2014. Vyvoj jazykovych schopnosti v preskolnim veku. Praha: Grada. ISBN 978-80-247-4240-3.

SMOLIK, F. - SEIDLOVA MALKOVA, G. 2011. Validity of language sample measures taken from structured elicitation procedures in Czech, Ceskoslovenska Psychologie, vol. 55, n. 5, pp. 448-458. ISSN 0009062X.

Slovnik sucasneho slovenskeho jazyka. A - G. 2006. BUZASSYOVA, K. - JAROSOVA, A. (Eds.). Bratislava: Veda. ISBN 978-80-224-0932-4.

Words: 6358

Characters: 44538 (24,7 standard pages)

Mgr. Zdenka Kumorová, PhD.

Department of Slovak Language and Literature

Faculty of Arts Faculty of Education

University Ss. Cyril and Methodius in Trnava

J. Herdu 2, 91701 Trnava

Slovakia

zdenka.kumorova@ucm.sk 